\title{
AN APPLICATION OF THE NEGATIVE MALMQUIST MODEL FOR VIETNAMESE GARMENT AND TEXTILES INDUSTRY
}

\author{
Thi Kim Lien NGUYEN \\ Thanh Dong University \\ Xuan-Huynh NGUYEN \\ Hanoi School of Business \& Management, Vietnam National University \\ Hong V. PHAM \\ Vietnam Institution of Science, Technology and Innovation
}

\begin{abstract}
:
The study purpose is to measure the performance of the Vietnamese garment and textiles industry by means of the Negative Malmquist model using the data envelopment analysis (DEA) method. The empirical results presented the efficient, inefficient cases, and average efficiency for all garment and textile companies in Vietnam during from 2016 to 2020. The main findings determined that five companies, including HTG, TET, MSH, M10, and BDG possessed efficiency scores in whole terms. An overall picture of the garment and textiles industry in Vietnam is used to evaluate the operational process. The research recommends a feasible alternative method to deal with inefficient cases.
\end{abstract}

Key words: negative malmquist model, data envelopment analysis, garment and textile company, efficiency

\section{INTRODUCTION}

Significant improvements in regional economy and social development are fundamental strengths necessary to boost the growth rate of the garment and textiles industry. This is as true worldwide as it is in Vietnam. The Vietnamese economy has grown rapidly since 1987, after adopting an opendoor policy and integrating global market into local affairs. Thus, many industries have benefit-ted to develop and expand the manufacturing sector with various product offerings; whereas, Vietnam's garment and textiles industry grew continuously, with an average rate of 17 percent, from 2015 to 2019; additionally, it also contributed to the gross domestic product of 16 percent in 2019. However, the impact of the COVID-19 pandemic from 2020 until present has decreased sharply, the total exports of 2020 were been down 3.8 percent compared to the year of 2019 [1]. Total exports depend on international markets such as the European Union, North America, China, etc. because they possess a large import scale and stable markets to simultaneously boost domestic employment and export trade growth [2]. From the year of 2019, the COVID-19 pandemic has impacted the garment and textiles industry in Vietnam directly and subsequently reduced the amount of total exports. Besides, the eco-nomic crisis was responsible for the sharp decline in the export quantity of the garment and textile industry [3].
On the contrary, economic development had fostered the development of the garment and textiles industry before the COVID-19 pandemic. Access to the World Trade Organization helped the Chinese garment industry to develop rapidly [4]. From a competitive context, social influences, and an overall understanding of corporate social responsibility have been major impact factors for the Vietnamese garment and textiles industry [5], and it has achieved considerable worth since joining the World Trade Organization in 2007. To effectively assess the performance of the Vietnamese garment and textiles industry, the study used the negative Malmquist model in DEA to evaluate garment and textiles companies located in Vietnam.

The negative Malmquist model is proposed to calculate the efficiency of the Vietnamese garment and textiles companies because this model can deal with the presence of negative data. Additionally, it can present the unlimited efficiency score with effective terms of decision-making units (DMU) in which determines separate efficiency in every term of each DMU. In this study, the collected data of 10 garment and textiles companies in Vietnam from 2016 to 2020 contained both negative values and positive values [6]; thus, we selected the negative Malmquist model to solve the negative values and escalate the efficiency score. 
The empirical results revealed the operational process, which described the growth progress be-fore the COVID-19 pandemic, then decreased in the year 2020 due in most part on account of the COVID-19 pandemic. Additionally, the study discussed a feasible solution to solve the inefficient terms and growth directions for the future. The empirical analysis process described full particularly acknowledgement of garment and textiles companies in Vietnam.

The paper is arranged, as follows:

Section 1 - general of the garment and textiles industry in Vietnam and research purpose;

Section 2 - literature review constituting past studies of the garment and textiles industry, coupled with the negative Malmquist model;

Section 3-mathematical equations offered by the negative Malmquist model and source of the raw data;

Section 4 - empirical results;

Section 5 - primary findings and related values;

Section 6 - main results, limitations, and possibility for future research.

\section{LITERATURE REVIEW}

The term "textile" is a primary period of the design, production, and distribution of yarn, cloth, and clothing, the raw materials include natural and synthetic. The term "garment" is sequential processes including laying, marking, cutting, stitching, checking, finishing, pressing, and packaging to convert raw materials into finished goods [7]. The garment and textile industry is formulated and developed around the world to supply the human's demand of fashion. To have a general information of the garment and textile industry, many researchers surveyed and analyzed this industry under different sides.

In the previous studies of the garment and textile industry, several authors used various approaches. Joshi and Singh measured the Indian garment industry via the Malmquist Productivity Index without the presence of negative data [8]. Lenzo et al., applied the Social Life Cycle Assessment to evaluate Italian textile production [9]. Le et al., explored perceived impacts on the garment and textiles industry of Vietnam from China's Belt and Road Initiative when applying both desk and in-depth interviews with 54 leaders and high-ranking officials [10]. Zhao et al., analyzed the primary factors that effected the Chinese garment and textiles in order to define the target market of the garment and textiles export trade through Analytical Hierarchy Process [11]. Wang et al., integrated three models, including supply chain operations reference, analytical network process, and fuzzy analytical hierarchy process in the multi-criteria decisionmaking model (MCDM) for garment and textile supplier selection [12]. In this study, we utilized the negative Malmquist model in the DEA method with the presence of negative data to evaluate the performance of 10 Vietnamese garment and textiles companies.

DEA has been developed and applied in performance assessment for more than 40 years, up to now it has various models with different characteristics.
Charnes-Cooper-Rhodes (CCR) model, Slacks-Based Measure (SBM) model, and epsilon-based measure (EBM) model are used to measure the performance for DMU by the ratio between inputs and outputs [13, 14, 15]; however, these models still exist the input and output limitations when they require the positive input and output values for each DMU [16].

The Malmquist model is a combined index to measure the productivity change of a DMU over time. It has been applied in various economic aspects, including manufacturing [17], energy [18], transportation [19], and education [20].

These papers investigated productivity performance with positive data; further, others studies have covered the productivity index with the presence of negative data.

Portela et al., [21] indicated the productivity change of bank branches with the presence of negative data. Tohidi et al., [22] gave an illustration of the Malmquist model in the presence of negative data. The extendedness of the Malmquist model can deal with the negative data when a DMU exists with negative values, therefore the negative Malmquist model was employed to measure the efficiency of the Vietnamese garment and textiles industry.

\section{MATERIALS AND METHODS Data Collection}

The Vietnamese garment and textiles industry includes 3 subsectors, including an up-stream sector (fiber production), a mid-stream sector (fabric production and dyeing), and a down-stream sector (garment manufacturing). The main components of the garment and textile industry are cotton, synthetic fibers, wool yarn, synthetic and natural filaments, and silk. To evaluate the garment and textile companies in Vietnam, the past operating progress of selected companies has been evaluated. To this end, the study chose 10 Vietnamese garment and textiles companies located in Vietstock (2021) [6] (see Table 1).

Analysing the effect of operating progress requires having complete and exact information related to financial re-ports to derive the actual value of input variables and out-put variables. Ten garment and textiles companies, operating during the period of 2016-2020, were observed ac-cording to their financial report posting in Vietstock (2020) [6]. Based on the principle of the negative Malmquist model in DEA, the quantity of input variables, as well as the quantity of output variables, indicated they could not overcome the total DMU's. Hence, three input factors were chosen, including current assets (CA), non-current assets (NA), and owner's equity (OE); and, two output factors, including revenue (RE), and net profit after tax (NP), were also selected. 
Table 1 List of 10 garment and textiles companies in Vietnam

\begin{tabular}{|c|l|c|}
\hline No. & Garment and textile companies & Abbreviation \\
\hline 1 & $\begin{array}{l}\text { Ha Noi Textile and Garment Joint Stock } \\
\text { Corporation }\end{array}$ & HSM \\
\hline 2 & $\begin{array}{l}\text { Hoa Tho Textile \& Garment Joint Stock } \\
\text { Corporation }\end{array}$ & HTG \\
\hline 3 & $\begin{array}{l}\text { Thanh Cong Textile Garment Invest- } \\
\text { ment Trading Joint Stock Company }\end{array}$ & TCM \\
\hline 4 & $\begin{array}{l}\text { Northern Textiles \& Garments Joint } \\
\text { Stock Company }\end{array}$ & TET \\
\hline 5 & $\begin{array}{l}\text { Nam Dinh Textile Garment Joint Stock } \\
\text { Corporation }\end{array}$ & NDT \\
\hline 6 & $\begin{array}{l}\text { Song Hong Garment Joint Stock } \\
\text { Company }\end{array}$ & MSH \\
\hline 7 & $\begin{array}{l}\text { Vietnam National Textile \& Garment } \\
\text { Group }\end{array}$ & VTG \\
\hline 8 & $\begin{array}{l}\text { Garmant 10 Corporation - Joint Stock } \\
\text { Company }\end{array}$ & BDG \\
\hline 9 & $\begin{array}{l}\text { Pro-trade Garment Joint Stock } \\
\text { Company }\end{array}$ \\
\hline 10 & $\begin{array}{l}\text { Nha Trang Textile Garment Joint Stock } \\
\text { Company }\end{array}$ & NTT \\
\hline
\end{tabular}

Source: Vietstock (2021) [6]

\section{Input factors:}

CA: The value of current assets that are sold, consumed, used, and exhausted in one year's time through standard business operations.

NA: The value of current assets that are invested on a longterm basis.

OE: All of the money a securities company must pay-off in the event of liquidation.

\section{Output factors:}

RE: All of the money that the garment and textile company receive from its business activities in which there has been no deduction of operating charges and taxes.

NP: The entire profitability of a garment and textiles company after deduction of interest and taxes.

From the actual data posted to Vietstock (2021) [6], the output variable of NP appeared to contain negative values. Thus, the negative Malmquist model in DEA with the function of dealing with the presence of negative data was considered to be particularly well-equipped to calculate garment and textile companies' efficiency.

\section{Negative Malmquist Model}

DEA is a useful statistical method utilized in operations research and economics for the estimation of a production frontier to assess the efficiency of DMU's. It uses a nonparametric method of benchmarking to measure the efficiency of operational research. According to the common principle of DEA, the efficiency of a DMU may be defined as the given ratio between outputs and inputs, where the Malmquist model presents the performance change in a Decision-Making Unit (DMU) between two consecutive terms (Tone, 2004) [23]. In this study, the Malmquist model was used with the presence of negative data for measuring the efficiency of Vietnamese garment and textiles companies from 2016 to 2020.

First, estimating the Catch-Up effect (CUI):

$$
C U I=\frac{D F_{0}^{t+1}\left(x_{0}^{t+1}, y_{0}^{t+1}\right)}{D F_{0}^{t}\left(x_{0}^{t}, y_{0}^{t}\right)}
$$

Second, calculating the Frontier-Shift effect (FSI):

$$
F S I=\left[\frac{D F_{0}^{t}\left(x_{0}^{t}, y_{0}^{t}\right)}{D F_{0}^{t+1}\left(x_{0}^{t}, y_{0}^{t}\right)} \times \frac{D F_{0}^{t}\left(x_{0}^{t+1}, y_{0}^{t+1}\right)}{D F_{0}^{t+1}\left(x_{0}^{t+1}, y_{0}^{t+1}\right)}\right]^{1 / 2}
$$

Third, conducting the Malmquist Productivity Index (MPI):

$$
M P I=\left[\frac{D F_{0}^{t}\left(x_{0}^{t+1}, y_{0}^{t+1}\right)}{D F_{0}^{t}\left(x_{0}^{t}, y_{0}^{t}\right)} \times \frac{D F_{0}^{t+1}\left(x_{0}^{t+1}, y_{0}^{t+1}\right)}{D F_{0}^{t+1}\left(x_{0}^{t}, y_{0}^{t}\right)}\right]^{1 / 2}
$$

If the score of the MPI is lower than the number "one", the company is considered not to have attained the efficiency score. On the contrary, if the score of the MPI is equal to or higher than the number "one", the company obtains an efficiency score. In this study, the MPI is integrated into the super-efficiency mode so that it exhibits the differential efficiency scores in efficient cases versus non-efficient cases.

\section{EMPIRICAL RESULTS Data analysis}

Based on a given list of 10 Vietnamese garment and textiles companies in Table 2, input and output variables have been selected and then summarized, as shown in Table 3 . The maximum value of $C A, N A, O E, R E$, and NP during the period of 2016-2020 attained as 10547264; 11431177; 7996099; 19101466; and 716338, respectively. The minimum value of CA, NA, OE, RE, and NP during the period from 2016 to 2020 was 17459 ; 40355; 68452; 22683; and -32216 , respectively. These values indicated that all input and output values were suitable for inclusion into the negative Malmquist model in the DEA method.

\begin{tabular}{|c|c|c|c|c|c|c|}
\hline $\begin{array}{c}\text { Varia- } \\
\text { bles }\end{array}$ & $\operatorname{ar}$ & $a$ & $A$ & DE & RE & NP \\
\hline Max & \multirow{4}{*}{2016} & & 50 & 1 & 154 & \\
\hline Ain & & & 572 & 68452 & & \\
\hline verage & & 1595229 & 1653801 & 1093226 & 329 & 118428 \\
\hline 8 & & 257 & & & & \\
\hline Max & \multirow{4}{*}{2017} & 947 & 1143 & 782 & 174 & 685174 \\
\hline rest & & & & 88 & & \\
\hline verage & & 172 & 174 & 115 & & \\
\hline SD & & 263 & 325 & 223 & & 19 \\
\hline Max & \multirow{4}{*}{2018} & 105 & 113 & 799 & & \\
\hline Min & & 55 & 49 & 97 & & \\
\hline iverage & & 194 & 172 & 1236 & & \\
\hline SD & & 292 & 323 & 227 & 52 & \\
\hline Max & \multirow{4}{*}{2019} & 934 & 1049 & 7939649 & 189 & \\
\hline Min & & & & 940 & & \\
\hline Average & & 1723 & 162 & 1274096 & 40 & 162867 \\
\hline SD & & \begin{tabular}{|l|}
2600143 \\
\end{tabular} & 2984311 & 2262577 & & \\
\hline Max & \multirow{4}{*}{2020} & 7433840 & 1022 & 7855136 & 139 & 569448 \\
\hline Min & & 66178 & 40355 & 100159 & & -25470 \\
\hline verage & & 1532 & 155 & 1305076 & 324 & 128814 \\
\hline & & 2050667 & 2913509 & 2241676 & 3795720 & 174731 \\
\hline
\end{tabular}

Table 2

Summary of the collected data

Source: Vietstock (2021) [6]. 
Table 3 Pearson's correlation coefficient

\begin{tabular}{|c|c|c|c|c|c|c|}
\hline Variables & Year & CA & NA & $\mathrm{OE}$ & RE & NP \\
\hline CA & \multirow{5}{*}{2016} & 1.0000 & 0.9937 & 0.9960 & 0.9926 & 0.9805 \\
\hline NA & & 0.9937 & 1.0000 & 0.9975 & 0.9808 & 0.9637 \\
\hline $\mathrm{OE}$ & & 0.9960 & 0.9975 & 1.0000 & 0.9814 & 0.9719 \\
\hline $\mathrm{RE}$ & & 0.9926 & 0.9808 & 0.9814 & 1.0000 & 0.9765 \\
\hline NP & & 0.9805 & 0.9637 & 0.9719 & 0.9765 & 1.0000 \\
\hline CA & \multirow{5}{*}{2017} & 1.0000 & 0.9904 & 0.9961 & 0.9923 & 0.9823 \\
\hline NA & & 0.9904 & 1.0000 & 0.9951 & 0.9779 & 0.9578 \\
\hline $\mathrm{OE}$ & & 0.9961 & 0.9951 & 1.0000 & 0.9828 & 0.9744 \\
\hline $\mathrm{RE}$ & & 0.9923 & 0.9779 & 0.9828 & 1.0000 & 0.9695 \\
\hline NP & & 0.9823 & 0.9578 & 0.9744 & 0.9695 & 1.0000 \\
\hline $\mathrm{CA}$ & \multirow{5}{*}{2018} & 000 & 0.9913 & 0.9971 & 0.9915 & 0.9073 \\
\hline NA & & 0.9913 & 1.0000 & 0.9941 & 0.9777 & 0.8534 \\
\hline $\mathrm{OE}$ & & 0.9971 & 0.9941 & 1.0000 & 0.9832 & 0.8982 \\
\hline $\mathrm{RE}$ & & 0.9915 & 0.9777 & 0.9832 & 1.0000 & 0.9061 \\
\hline NP & & 0.9073 & 0.8534 & 0.8982 & 0.9061 & 1.0000 \\
\hline CA & \multirow{5}{*}{2019} & 1.0000 & 0.9838 & 0.9963 & 0.9926 & 0.8933 \\
\hline$N A$ & & 0.9838 & 1.0000 & 0.9887 & 0.9729 & 0.8099 \\
\hline $\mathrm{OE}$ & & 0.9963 & 0.9887 & 1.0000 & 0.9834 & 0.8818 \\
\hline RE & & 0.9926 & 0.9729 & 0.9834 & 1.0000 & 0.8902 \\
\hline$N P$ & & 0.8933 & 0.8099 & 0.8818 & 0.8902 & 1.0000 \\
\hline CA & \multirow{5}{*}{2020} & 1.0000 & 0.9720 & 0.9935 & 0.9916 & 0.9442 \\
\hline$N A$ & & 0.9720 & 1.0000 & 0.9849 & 0.9560 & 0.8631 \\
\hline $\mathrm{OE}$ & & 0.9935 & 0.9849 & 1.0000 & 0.9740 & 0.9345 \\
\hline $\mathrm{RE}$ & & 0.9916 & 0.9560 & 0.9740 & 1.0000 & 0.9268 \\
\hline NP & & 0.9442 & 0.8631 & 0.9345 & 0.9268 & 1.0000 \\
\hline
\end{tabular}

According to the principle of the DEA method, the collected data must be checked using Pearson's correlation coefficient to ensure the appropriate relationship be-tween input and inputs; output and output; and, input and output exist before their application into the DEA method. The relationship between two variables is always isotonic with the value exhibited from -1 to +1 , it has a perfect linear relationship as near to \pm 1 , a strong correlation as near to \pm 0.5 and \pm 0.8 , a medium correlation as near to \pm 0.3 and \pm 0.49 , and a low correlation occurs when lower than \pm 0.29 [24]. All variables with unqualified Pear-son's correlation are to be removed prior to summarization. In this research, the Pearson's correlations of the 10 Vietnamese garment and textiles companies maintained variables with values from 0.8099 to 1 , so they are said to have a good linear relationship. Therefore, all collected data were appreciable in order to apply to the negative Malmquist model in the DEA method.

\section{Measurement of performance}

In recent years, the garment and textiles industry of Vietnam has developed markedly. The negative Malmquist model not only deals with negative data but also provides separate scores for each DMU in each of the years observed. In this research, a determination of the efficiency scores of the Vietnamese garment and textiles companies from 2016 to 2020 was conducted (see Table 4).

Table 4

Efficiency of 10 Vietnamese garment and textiles companies

\begin{tabular}{|c|r|r|r|c|c|l|}
\hline DMUs & $\mathbf{2 0 1 6}$ & $\mathbf{2 0 1 7}$ & $\mathbf{2 0 1 8}$ & $\mathbf{2 0 1 9}$ & $\mathbf{2 0 2 0}$ & Average \\
\hline HSM & 0.4222 & 0.4819 & 0.4144 & 0.4550 & 0.3277 & 0.4202 \\
\hline HTG & 1.0657 & 1.5185 & 2.0970 & 1.9527 & 1.0750 & 1.5418 \\
\hline TCM & 0.6234 & 0.9178 & 1.1473 & 1.1119 & 1.3590 & 1.0319 \\
\hline TET & 8.8384 & 7.2995 & 6.2561 & 6.6120 & 5.2791 & 6.8570 \\
\hline NDT & 0.3943 & 0.3740 & 0.4006 & 0.4904 & 0.5163 & 0.4351 \\
\hline MSH & 2.4663 & 2.2255 & 8.0508 & 16.2945 & 2.7867 & 6.3648 \\
\hline VGT & 1.0000 & 1.0508 & 1.0395 & 1.0395 & 0.9093 & 1.0078 \\
\hline M10 & 1.4858 & 1.2862 & 1.0444 & 1.2247 & 1.5275 & 1.3137 \\
\hline BDG & 2.0869 & 2.1763 & 2.3327 & 2.4530 & 2.5412 & 2.3180 \\
\hline NTT & 0.5354 & 0.4824 & 0.5004 & 0.7971 & 0.7987 & 0.6228 \\
\hline Average & 1.8918 & 1.7813 & 2.3283 & 3.2431 & 1.7121 & 2.1913 \\
\hline Max & 8.8384 & 7.2995 & 8.0508 & 16.2945 & 5.2791 & 6.8570 \\
\hline Min & 0.3943 & 0.3740 & 0.4006 & 0.4550 & 0.3277 & 0.4202 \\
\hline SD & 2.5411 & 2.0481 & 2.6594 & 4.9305 & 1.4891 & 2.3996 \\
\hline
\end{tabular}

Observing Table 4, there were five companies, including HTG, TET, MSH, M10, and BDG with scores under the number one and that always achieved efficiency in whole terms; although their scores experienced large-scale annual fluctuations. The efficiency scores of $\mathrm{MSH}$ reduced somewhat from 2.4663 in 2016 to 2.2255 in 2017, then they increased sharply for the next two years, with scores as 8.0508 (2018) and 16.2945 (2019), and continuously dropped in the year 2020. TET maintained a downward trend year-to-year except for rising slightly from 6.2561 (2018) to 6.612 (2019). The performance of M10 declined for three consecutive years, and then increased the following two consecutive years; on the contrary, HTG enjoyed an upward trend within three consecutive years and then suffered a downturn for the next two consecutive years. Minor score fluctuations occurred from 2.0869 to 2.5412 , so that BDG was the only company to obtain efficiency with an upward trend for the entire term. TCM and VGT experienced both efficiency and inefficiency; whereas TCM increased continually except for reducing efficiency in the year 2019. VGT had two inefficient years and three efficient years; so, VGT had only one upward-trending term from 1 (2016) to 1.0508 (2017), then declined consecutively; but it still obtained efficiency in four consecutive years from 2016 to 2019. Finally, the three remaining companies, including HSM, NDT, and NTT did not achieve efficiency in whole terms despite their scores showing an upward trend.

In addition, the negative Malmquist model presented the average score for all garment and textiles companies based on their scores year-to-year. TET had the highest average efficiency score when it achieved the average score of 6.8570; in contrast, HSM had the lowest average efficiency score when its score was 0.4202 . Besides, this model also determined the average, maximum and mini-mum scores occurring in each year. The average score for the year 2019 held the highest valuation, but the influence of the COVID19 pandemic impacted the average score for the year 2020 to have the lowest valuation. 
Additionally, the year of 2019 held the highest efficiency score and the year 2020 had the lowest efficiency score for both maximum scores and minimum scores present.

\section{DICUSSIONS}

Vietnam is one of the nations in the world where the export value of the garment and textiles industry always achieves a large valuation. Statistics (2021) have indicated that the total export value in the garment and textiles industry in Vietnam increased consecutively from 24.7 billion USD to 39 billion USD during 2014 to 2019; however, the COVID-19 pandemic impacted directly on the market-place and caused a recession while reducing the total export value 35.2 billion USD in 2020 (See Figure 1). Therefore, the garment and textiles industry in Vietnam experienced growth before the COVID-19 outbreak influenced Vietnam, the region, and globally. The total export values for the year 2020 declined sharply so that the effective operation of the garment and textiles companies in Vietnam dropped sharply with the average efficiency score from 3.2431 in 2019 to 1.7121 in 2020.

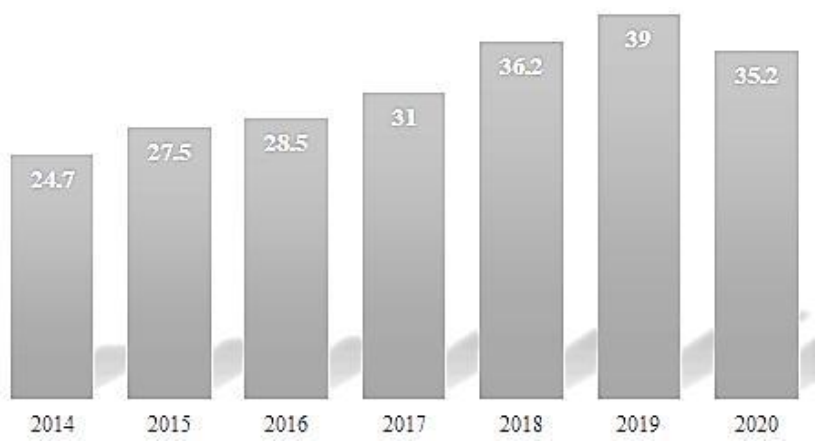

Fig. 1 Total export value of Vietnamese textiles and garments from 2014 to 2020 (billion USD)

Source: Statistics (2021) [25].

The above analysis results, as shown in Table 4, present 50 scores; whereas, there were 32 efficient cases and 18 inefficient cases. The efficiency score of several companies, such as HTG, TET, or MSH, made a sharp downward trend with deducted 2020 values of 0.8777 ; 1.3329; and 13.5078, respectively. Empirical results revealed that MSH obtained efficient performance in whole terms, but its scores fluctuated at the highest level, especially during 2020. In addition, three companies, including HSM, NDT, and NTT, did not attain efficiency in whole terms. HSM had the worst performance because its average score gave the lowest value.

From the efficiency scores and total export value of the Vietnamese garment and textiles industry, the Vietnam-ese garment and textile companies has been greatly impacted by the COVID-19 pandemic, both locally and glob-ally. Hence, the companies examined as part of this study should reduce the cost of input variables and increase the value of output variables based on the characteristics of a data envelopment analysis approach; moreover, the government should extend the import tax exemptions for raw materials, supplies, and components for the manufacturing process to go forward. In this way, export production would rise and support companies would expand research and development activities, technology transfers, and product innovation.

\section{CONCLUSIONS}

The Vietnamese garment and textiles industry presents a marked variation in its operational performance from 2016 to 2020 , as conducted by the negative Malmquist model. The empirical results of this modelling exhibited a separate efficiency score every year and an average efficiency score for the period of 2016-2020; moreover, the study revealed the considerable impact of the COVID-19 pandemic for the garment and textiles industry in Vietnam.

The study exhibited the process of business operations and improved efficiency score for the Vietnamese garment and textiles industry. Analytic results determined efficient and inefficient cases for 10 companies. Such measurement is fundamental to the support of enterprises by identifying their capable operations to extend improved operational performance in the near future. The main findings contribute to maintaining and developing a sustainable efficient garment and textiles industry in Vietnam. This industry contributes considerably to the GDP, and it will provide an effective operational orientation in the future.

Although the study uniquely concerned the performance of the garment and textiles companies in Vietnam, there are still limitations existing. Future research is necessary to compare the Vietnamese garment and textiles industry with other nations in order to have a larger overview of the global garment and textiles industry and to make a comparison for the growing region. Further study has the possibility to give more inputs and outputs such as costs of manufacturing, employee, and so on to insure a deeper observation.

\section{REFERENCES}

[1] T. Nguyen. Seizing Investment Opportunities in Vietnam's Garment and Textile Industry. Vietnam Briefing. 2020. Available online: https://www.vietnam-briefing.com/news/seizing-investment-opportunities-vietnams-textile-garment-industry.html/ [April 5, 2021].

[2] J.N. Zhao, J. Li, and L.T. Li. "An Analysis on the Target Market of China's Textile and Garment Export Trade". Procedia Engineering, 2011. vol.15, pp. 4718-4722.

[3] T. Jantarakolica and P. Chalermsook. "Thai Export under Exchange Rate Volatility: A Case Study of Textile and Garment Products". Procedia - Social and Behavioral Sciences, 2012. vol. 40, pp. 751-755,

[4] C. Chen and H. Shih. "The impact of WTO accession on the Chinese garment industry". Journal of Fashion Marketing and Management, 2004. vol. 8, no. 2, pp. 221-229.

[5] L.T.H. Van and P.A. Nguyen. "Corporate Social Responsibility and SMEs in Vietnam: A Study in the Textile and Garment Industry". Journal of Risk Financial Management, 2019. vol. 12, pp. 1-14.

[6] Vietstock. Available online: https://finance.vietstock.vn/. Accessed on 28/02/2021.

[7] A. Singh and K. Nijhar. "Garment costing". Garment Manufacturing Technology, 2015. pp. 447-467.

[8] R.N. Joshi and S.P. Singh. "Estimation of total factor productivity in the Indian garment industry". Journal of Fashion Marketing and Management, 2010. vol. 14, no. 1, pp. 145-160. 
[9] P. Lenzo, M. Traverso, R. Salomone, and G. Ioppolo. "Social Life Cycle Assessment in the Textile Sector: An Italian Case Study". Sustainability, 2017. vol. 9, no. 11, pp. 1-21.

[10] Q.A. Le, V.A. Tran, and V.L.D. Nguyen. "The Belt and Road Initiative and Its Perceived Impacts on the Textile and Gar-ment Industry of Vietnam". Journal of Open Innovation: Technology, Market, and Complexity, 2019. vol. 5, no. 3, pp. 1-14.

[11] J.N. Zhao, J. Li and L.T. Li. "An Analysis on the Target Market of China's Textile and Garment Export Trade". Procedia Engineering, 2011. vol. 15, pp. 4718-4722.

[12] C.N. Wang, V.T.H. Viet, T.P. Ho, and V.T. Nguyen. "MultiCriteria Decision Model for the Selection of Suppliers in the Textile Industry". Symmetry, 2020. vol. 12, pp. 1-12.

[13] A. Charnes, W.W. Cooper and E. Rhodes "Measuring the Efficiency of Decision-Making Units". European Journal of Operational Research, 1978. vol. 2, pp. 429-444.

[14] K. Tone. "A slacks-based measure of efficiency in data envelopment analysis". European Journal of Operational Re-search, 2001. vol. 130, no. 3, pp. 498-509.

[15] K. Tone and M. Tsutsui. "An epsilon-based measure of efficiency in DEA - A third pole of technical efficiency". European Journal of Operational Research, 2010. vol. 207, pp. 9-22.

[16] R.B. Huang and Y.H. Li. "Undesirable input-output twophase DEA model in an environmental performance audit". Mathematical and Computer Modelling, 2013. vol. 58, no. 5-6, pp. 971-979.

[17] F.H.F. Liu and P.H. Wang. "DEA Malmquist productivity measure: Taiwanese semiconductor companies". International Journal of Production Economics, 2008. vol. 112, no. 1, pp. 367-379.

\section{Thi Kim Lien Nguyen}

Thanh Dong University

Scientific Research-International Cooperation

Hai Duong 171967, Vietnam

e-mail: lienntk@thanhdong.edu.vn

Xuan-Huynh Nguyen (Corresponding author)

Hanoi School of Business \& Management

Vietnam National University

Hanoi 100000, Vietnam

e-mail: huynhnx@hsb.edu.vn

\section{Hong V. Pham}

Vietnam Institution of Science

Technology and Innovation

Hanoi, 100000, Vietnam

e-mail: phamvanhong1973@gmail.com
[18] J.P. Liu, Q.R. Yang, and L. He. "Total-Factor Energy Efficiency (TFEE) Evaluation on Thermal Power Industry with DEA, Malmquist and Multiple Regression Techniques". Energies, 2017. vol. 10, pp. 1-14.

[19] X. Jiang, J. Ma, H. Zhu, X. Guo, and Z. Huang. "Evaluating the Carbon Emissions Efficiency of the Logistics Industry Based on a Super-SBM Model and the Malmquist Index from a Strong Transportation Strategy Perspective in China". International Journal of Environmental Research and Public Health, 2020. vol. 17, pp. 1-19.

[20] C.N. Wang, H. Tibo, V.T. Nguyen, and D.H. Duong. "Effects of the Performance-Based Research Fund and Other Fac-tors on the Efficiency of New Zealand Universities: A Malmquist Productivy Apporach". Sustainability, 2020. vol. 12, pp. 1-18.

[21] M.C. A.S. Portela and E. Thanassoulis. "Malmquist-type in-dices in the presence of negative data: An application to bank branches". Journal of Banking \& Finance, 2010. vol. 34, no. 7, pp. 1472-1483.

[22] G. Tohidi, S. Razavyan, and S. Tohidnia. "Profit Malmquist Index and Its Global Form in the Presence of the Negative Data in DEA". Journal of Applied Mathematics, 2014, Article ID 276092, pp. 1-8.

[23] K. Tone. "Dealing with Undesirable Outputs in DEA: A Slacks-Based Measure (SBM) Approach". North American Productivity Workshop 2004, Toronto, 23-25 June 2004, pp. 44-45.

[24] M.M Mukaka. "Statistics Corner: A guide to appropriate use of Correlation coefficient in medical research". Malawi Medical Journal, 2012. vol. 24, no. 3, pp. 69-71.

[25] Statistic. Available online: https://www.statista.com/statistics/727541/apparel-market-growth-global/. Accessed on $15 / 3 / 2021$. 